\title{
5. DENSITY OF OLD OCEANIC CRUST: AN ESTIMATE DERIVED FROM DOWNHOLE LOGGING ON ODP LEG 102 1
}

\author{
R. L. Carlson and K. R. Snow, Department of Geophysics and Geodynamics Research Institute, Texas A\&M \\ University, College Station, Texas ${ }^{2}$ \\ and
}

R. H. Wilkens, Department of Earth, Atmospheric and Planetary Sciences, Massachusetts Institute of Technology, Cambridge, Massachusetts ${ }^{3}$

\begin{abstract}
Given reliable statistical relationships between velocity and density, the density structure and average density of the oceanic crust can be estimated from seismic-survey data. Owing to the low porosity of lower crustal rocks (Layer 3), a velocity-density relation derived from laboratory measurements,

$$
\rho=(3.81 \pm 0.02)-(5.99 \pm 0.11) / \mathrm{V}_{p},
$$

can be used to estimate the in-situ density of the lower oceanic crust, whereas downhole logging results from holes in young oceanic crust suggest that the velocity-density relation for the shallow crust (Layer 2) is significantly different from the laboratory relation. However, the velocity structure of Layer 2 changes appreciably with age, and the velocitydensity relation for young crust may not be appropriate for crust more than $20 \mathrm{Ma}$ in age. To resolve this question, we have analyzed gamma density, neutron porosity, and long-spaced sonic logging data from a 326-m interval in DSDP Hole $418 \mathrm{~A}$, where the age of the crust is about $110 \mathrm{Ma}$. Our results indicate that the velocity-density relation for old oceanic crust is best described by the laboratory data. We therefore conclude that velocity-density relations for uppermost portions of young and old oceanic crust are appreciably different. The average density of old oceanic crust is about $2.85 \mathrm{Mg} / \mathrm{m}^{3}$ and is comparable with the estimated mean density of continental crust, 2.87 to $3.0 \mathrm{Mg} / \mathrm{m}^{3}$.
\end{abstract}

\section{INTRODUCTION}

An important objective of drilling into oceanic basement is to ascertain the properties of the formation (density, porosity, seismic velocity, hydraulic conductivity, etc.), their variation with age, depth, and composition, and their influence on physical and chemical processes. At the drill site, various tools and techniques lend themselves to meeting this objective. Among them are direct observation of recovered cores, standard downhole logs, and specialized downhole experiments, such as long-spaced resistivity (e.g., Becker et al., 1982) and oblique seismic experiments (e.g., Stephen, 1985). Away from the borehole, the properties of the crust must be inferred largely from seismic-refraction data. Thus, establishing statistically valid relationships between seismic velocity and density or porosity is an important objective.

The density structure and average density of the oceanic crust also have important implications for a variety of problems including interpretations of gravity data, the variation of lithospheric buoyancy in relation to age, and the role and fate of the crust in subduction processes. In a previous study, Carlson and Raskin (1984) used ophiolite lithostratigraphy, laboratory studies of density and $P$-wave velocity in oceanic basalts, diabases, and gabbros, and downhole-logging data to estimate both insitu velocity-density relationships and the density structure and

\footnotetext{
${ }^{1}$ Salisbury, M. H., Scott, J. H., et al., 1988. Proc. ODP, Sci. Results, 102: College Station, TX (Ocean Drilling Program).

2 Address: Geodynamics Research Institute, Texas A\&M University, College Station, TX 77843.

${ }^{3}$ Earth Resources Laboratory, Department of Earth, Atmospheric and Planetary Sciences, Massachusetts Institute of Technology, Cambridge, MA 02142 (present address: Department of Geology and Geophysics, University of Hawaii, 2525 Correa Road, Honolulu, HI 96822).
}

average density of the oceanic crust from those relationships. However, all of the logging data used to constrain their model is from DSDP holes in young (less than $7 \mathrm{Ma}$ ) oceanic crust, whereas it is known from seismic studies that the velocity structure of Layer 2, and hence the physical state of Layer 2, change markedly with age because of progressive alteration and infilling of voids by alteration products (e.g., Houtz and Ewing, 1976; Christensen and Salisbury, 1975). Thus, the objective of this paper is to determine the relationship between in-situ density and seismic velocity in old Layer 2 basalts at Hole 418A.

\section{BACKGROUND}

The statistical velocity-density models of Carlson and Raskin (1984) and their relationship to previous DSDP downhole-logging results are summarized in Figure 1.

Line A was obtained from a least-squares fit of bulk densities $(\rho)$ on the inverse of compressional-wave velocities $\left(\mathrm{V}_{p}\right)$ measured in the laboratory under water-saturated conditions and at $100 \mathrm{MPa}$ confining pressure. Upper crustal (Layer 2) lithologies are represented in the data set by basalts recovered from the seafloor by drilling, whereas lithologies thought to be representative of the lower oceanic crust (diabases and various gabbroic rocks) are taken from ophiolites (e.g., Salisbury and Christensen, 1978; Christensen and Salisbury, 1982; Christensen and Smewing, 1981; Fountain et al., 1975; Carlson and Wilkens, 1983). The distribution in Figure 1 is strongly linear (see Carlson and Raskin, 1984), and the best-fit linear equation is

$$
\rho=(3.81 \pm 0.02)-(5.99 \pm 0.11) / \mathrm{V}_{p},
$$

(where $\rho$ is in $\mathrm{Mg} / \mathrm{m}^{3}$ and $\mathrm{V}_{p}$ is in $\mathrm{km} / \mathrm{s}$ ) with a coefficient of determination $\left(\mathrm{r}^{2}\right)$ of 0.86 and an rms error of $0.07 \mathrm{Mg} / \mathrm{m}^{3}$.

Equation (1) applies to the lower oceanic crust, but Carlson and Raskin recognized that it may not apply to the extrusives of 


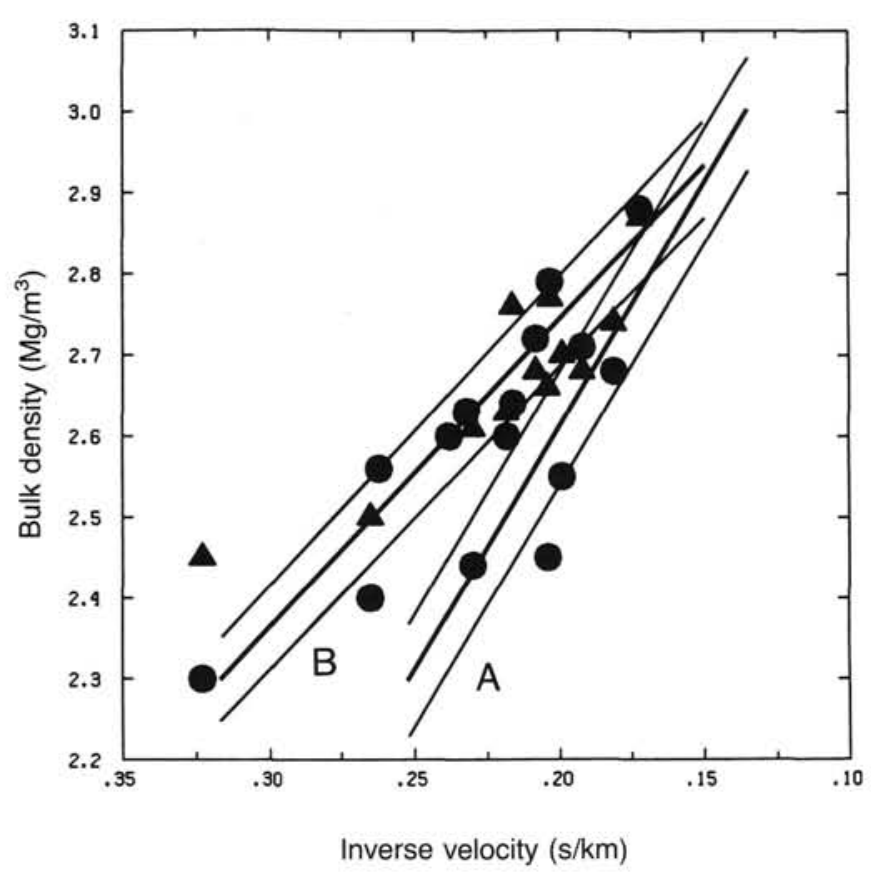

Figure 1. Velocity-density relations for the oceanic crust (from Carlson and Raskin, 1984). Line A is least-squares fit to laboratory densities and velocities in basalts, diabases, and gabbroic rocks. Line B is approximate time-average relation for fresh basalt and seawater. Light lines indicate standard errors. Circles and triangles indicate averages from various downhole logs: circles $=$ averaged gamma densities; triangles $=$ av eraged neutron porosities (see text).

Layer 2 because the data are affected (or biased) by seawater alteration of basalts in the upper few tens of meters of basement and because these data cannot reflect large-scale porosity. To overcome this difficulty, Carlson and Raskin (1984) calculated the coefficients of a time-average equation from the properties of seawater $\left(\rho=1.025 \mathrm{Mg} / \mathrm{m}^{3}, \mathrm{~V}_{p}=1.5 \mathrm{~km} / \mathrm{s}\right)$ and those of a zero-porosity, fresh basalt $\left(\rho=2.93 \mathrm{Mg} / \mathrm{m}^{3}, \mathrm{~V}_{p}=6.65 \mathrm{~km} / \mathrm{s}\right)$ estimated by statistical methods. This time-average relation is

$$
\rho=(3.5 \pm 0.2)-(3.79 \pm 0.1) / \mathrm{V}_{p},
$$

and is indicated by line B in Figure 1.

Equation (2) is ad hoc and therefore requires an independent test. Also shown in Figure 1 are velocities and densities from downhole logging at a number of DSDP holes: Hole 396B (Kirkpatrick, 1979), Hole 417D (Salisbury et al., 1980), Hole 504B, Legs 69 and 70 (Cann and Von Herzen, 1983), and Holes 504B (Leg 83), 556, 558, and 564 (Carlson and Raskin, 1984). There is considerable scatter in these data, but they do tend to follow the trend defined by equation (2), as opposed to that defined by the laboratory data. Consequently, the preferred model of Carlson and Raskin (1984) is one in which upper crustal densities $\left(\mathrm{V}_{p}<6.65 \mathrm{~km} / \mathrm{s}\right)$ are calculated from equation (2), and lower crustal densities $\left(\mathrm{V}_{p}>6.65 \mathrm{~km} / \mathrm{s}\right)$ are calculated from equation (1).

Density structures and mean crustal densities calculated from a number of average velocity structure models (Christensen and Salisbury, 1975; Houtz and Ewing, 1976; Raitt, 1963; Shor, 1971; Purdy, 1983) are summarized in Table 1 . It is worth noting that upper crustal densities estimated by using equations (1) and (2) are appreciably different-Layer 2 densities differ by 0.1 to $0.2 \mathrm{Mg} / \mathrm{m}^{3}$, and Layer $2 \mathrm{~A}$ values differ by about $0.3 \mathrm{Mg} / \mathrm{m}^{3}$. Because the downhole log data used to test equation (2) were all from holes in young oceanic crust, it is not clear which model applies to most of the oceanic crust (i.e., to crust more than 20 Ma or so in age) where Layer $2 \mathrm{~A}$ is largely absent. Downholelogging data acquired at Site 418A on ODP Leg 102 afford an opportunity to determine which, if either, equation applies to old oceanic crust.

\section{ANALYSIS AND RESULTS}

Site 418 is located east of Florida at the southern end of the Bermuda Rise. Hole 418A was drilled on DSDP Legs 51-53 (Donnelly, Francheteau, et al., 1980) and penetrated $544 \mathrm{~m}$ of basaltic basement, but downhole logging was unsuccessful because a tool was apparently lost in the hole on the first logging run. Because this site is located on magnetic anomaly $M 0$ (about $110 \mathrm{Ma}$ ) and basement penetration is significant, Hole $418 \mathrm{~A}$ is ideal for acquiring a comprehensive baseline suite of borehole geophysical data for old oceanic crust. Consequently, JOIDES Resolution returned to Site 418 in 1985 to conduct a wide range of downhole experiments (Salisbury, Scott, et al., 1986).

Of interest for the purposes of this study are the sonic, gamma density, and neutron porosity logs. Owing to the possible presence of the lost tool near the bottom of the hole and a ledge, or bridge, at about $480 \mathrm{~m}$ below seafloor (mbsf), only the 326-m interval between 462 and 788 mbsf was logged with all three tools in the open hole. The logged interval extends from the middle of Unit 5 to the bottom of Unit 13 (see fig. 5 of Shipboard Scientific Party, 1986). This interval consists largely of pillow lavas, although a basaltic breccia between 500 and 515 mbsf (Subunit 6A) and significant massive flows between 675 and 687 mbsf (Units 9 and 10) are included. The massive units at the top and bottom of the hole were not successfully logged with this suite of tools.

In principle, the relationship between sonic velocity and density can be obtained by cross-plotting the traveltime and density values from the logs. In practice, several difficulties arise:

1. Although the conventional logs are generally of good quality (fig. 5 of Shipboard Scientific Party, 1986), the roughness of the borehole wall can prevent the pad of the lithodensity tool from making good contact with the formation, and gamma density values are suspiciously low over some intervals, as shown in Figure 2 . In particular, the density log is very "spikey" between 525 and $600 \mathrm{mbsf}$, and the apparent densities are often less than $2.0 \mathrm{Mg} / \mathrm{m}^{3}$. These low densities suggest porosities in excess of $40 \%$ and correspondingly low sonic velocities that are not reflected in either the velocity or neutron porosity logs (see plate 2 of Shipboard Scientific Party, 1986). The density log thus requires editing.

We edited the gamma density log by comparing it with densities calculated from the raw neutron porosity log. Because the raw neutron porosities overestimate in-situ porosities by $6 \%$ or more, densities calculated from those porosities are reasonable minimum estimates of in-situ densities. For consistency with the analysis of Carlson and Raskin (1984), we used a grain density of $2.93 \mathrm{Mg} / \mathrm{m}^{3}$, which is not significantly different from the mean grain densities of $2.91 \pm 0.04 \mathrm{Mg} / \mathrm{m}^{3}$ (Hamano, 1980) and $2.92 \mathrm{Mg} / \mathrm{m}^{3}$ (Christensen et al., 1980) of basalts from Sites 417 and 418 . The calculated reasonable minimum density and gamma density logs for the interval between 500 and 700 mbsf are illustrated in Figure 2. The results indicate that the gamma density log values are anomalously low between 525 and 600 mbsf. Therefore, we have not used the density log for that interval.

2. Densities can be estimated from neutron porosities by choosing a suitable grain density, but two problems arise in this procedure. First, neutron "porosity" is actually a measure of hydrogen and other elements (silicon, chlorine, boron, and gadolinium) in the formation. Raw values assume that hydrogen 
Table 1. Summary of average velocity-structure models and density structures.

\begin{tabular}{|c|c|c|c|c|c|}
\hline \multirow[b]{2}{*}{ Reference } & \multicolumn{3}{|c|}{ Model } & \multirow{2}{*}{$\begin{array}{c}\begin{array}{c}\text { Laboratory } \\
\text { data }\end{array} \\
\begin{array}{c}\text { Density } \\
\left(\mathrm{Mg} / \mathrm{m}^{3}\right)\end{array}\end{array}$} & \multirow{2}{*}{$\begin{array}{c}\begin{array}{c}\text { Laboratory and } \\
\text { log data }\end{array} \\
\text { Density } \\
\left(\mathrm{Mg} / \mathrm{m}^{3}\right)\end{array}$} \\
\hline & Layer & $\begin{array}{l}\text { Thickness } \\
(\mathrm{km})\end{array}$ & $\begin{array}{l}\text { Velocity } \\
(\mathrm{km} / \mathrm{s})\end{array}$ & & \\
\hline \multirow[t]{3}{*}{ Raitt (1963) } & 2 & $1.71 \pm 0.75$ & $5.07 \pm 0.63$ & $2.63 \pm 0.15$ & $2.75 \pm 0.09$ \\
\hline & 3 & $4.86 \pm 1.42$ & $6.69 \pm 0.26$ & $2.91 \pm 0.04$ & $2.91 \pm 0.04$ \\
\hline & Mean & & & $2.84 \pm 0.06$ & $2.87 \pm 0.04$ \\
\hline \multirow[t]{3}{*}{ Shor (1971) } & 2 & $1.49 \pm 0.98$ & $5.19 \pm 0.69$ & $2.66 \pm 0.16$ & $2.77 \pm 0.10$ \\
\hline & 3 & $4.62 \pm 1.30$ & $6.81 \pm 0.16$ & $2.93 \pm 0.03$ & $2.93 \pm 0.03$ \\
\hline & Mean & & & $2.86 \pm 0.06$ & $2.89 \pm 0.04$ \\
\hline \multirow[t]{3}{*}{ Christensen and Salisbury (1975) } & 2 & $1.39 \pm 0.5$ & $5.04 \pm 0.69$ & $2.62 \pm 0.17$ & $2.75 \pm 0.10$ \\
\hline & 3 & $4.97 \pm 1.25$ & $6.73 \pm 0.19$ & $2.92 \pm 0.04$ & $2.92 \pm 0.04$ \\
\hline & Mean & & & $2.85 \pm 0.05$ & $2.88 \pm 0.04$ \\
\hline Christensen and Salisbury (1975) & 2 & 1.6 & 4.4 & $\mathrm{~b}_{2.45} \pm 0.03$ & $b_{2.64} \pm 0.01$ \\
\hline \multirow{3}{*}{ Sonobuoy type I } & $3 \mathrm{~A}$ & 1.2 & 6.4 & $2.87 \pm 0.03$ & $2.91 \pm 0.01$ \\
\hline & 3B & 4.8 & 7.1 & $2.97 \pm 0.03$ & $2.97 \pm 0.03$ \\
\hline & Mean & & & $2.84 \pm 0.02$ & $2.89 \pm 0.02$ \\
\hline Christensen and Salisbury (1975) & 2 & 1.6 & 4.4 & $\mathrm{~b}_{2.45} \pm 0.03$ & $b_{2.64} \pm 0.01$ \\
\hline \multirow[t]{3}{*}{ Sonobuoy type II } & $3 \mathrm{~A}$ & 3.0 & 6.8 & $2.93 \pm 0.03$ & $2.93 \pm 0.03$ \\
\hline & 3B & 2.6 & 7.5 & $3.01 \pm 0.01$ & $3.01 \pm 0.02$ \\
\hline & Mean & & & $2.85 \pm 0.02$ & $2.89 \pm 0.01$ \\
\hline Houtz and Ewing (1976) & $2 \mathrm{~A}$ & $0.3 \pm 0.1$ & $3.74 \pm 0.50$ & $2.21 \pm 0.22$ & $2.49 \pm 0.14$ \\
\hline \multirow[t]{4}{*}{ Atlantic } & 2B & $1.0 \pm 0.1$ & $5.13 \pm 0.38$ & $2.64 \pm 0.09$ & $2.76 \pm 0.06$ \\
\hline & $2 \mathrm{C}$ & $1.0 \pm 0.3$ & $6.05 \pm 0.22$ & $2.82 \pm 0.05$ & $2.87 \pm 0.03$ \\
\hline & 3 & ${ }^{a} 4.97 \pm 1.25$ & $6.83 \pm 0.21$ & $2.93 \pm 0.04$ & $2.93 \pm 0.04$ \\
\hline & Mean & & & $2.85 \pm 0.04$ & $2.88 \pm 0.03$ \\
\hline Houtz and Ewing (1976) & $2 \mathrm{~A}$ & $0.4 \pm 0.1$ & $3.74 \pm 0.35$ & $2.08 \pm 0.18$ & $2.41 \pm 0.11$ \\
\hline \multirow[t]{4}{*}{ Pacific } & 2B & $0.8 \pm 0.1$ & $5.28 \pm 0.39$ & $2.68 \pm 0.09$ & $2.78 \pm 0.05$ \\
\hline & $2 \mathrm{C}$ & $0.9 \pm 0.4$ & $6.12 \pm 0.18$ & $2.83 \pm 0.04$ & $2.88 \pm 0.02$ \\
\hline & 3 & ${ }^{a} 4.97 \pm 1.25$ & $6.90 \pm 0.17$ & $2.94 \pm 0.03$ & $2.94 \pm 0.03$ \\
\hline & Mean & & & $2.85 \pm 0.03$ & $2.89 \pm 0.03$ \\
\hline \multirow[t]{5}{*}{ Purdy (1983) } & $2 \mathrm{~A}$ & 0.38 & 5.30 & ${ }^{b} 2.68 \pm 0.03$ & $b_{2.78} \pm 0.01$ \\
\hline & 2B & 1.93 & 6.10 & $2.83 \pm 0.03$ & $2.88 \pm 0.01$ \\
\hline & $3 \mathrm{~A}$ & 1.55 & 6.86 & $2.94 \pm 0.03$ & $2.94 \pm 0.03$ \\
\hline & 3B & 3.15 & 7.06 & $2.96 \pm 0.03$ & $2.96 \pm 0.03$ \\
\hline & Mean & & & $2.90 \pm 0.01$ & $2.92 \pm 0.01$ \\
\hline
\end{tabular}

a Thickness of layer taken from the average structure of Christensen and Salisbury (1975).

b Calculated standard deviations do not include the effect of variability in crustal structure.

occurs only in pore waters, but in the oceanic basement, particularly at old sites, much of the hydrogen occurs in alteration products such as smectite. For this reason, among others, neutron porosities overestimate the formation porosity. This problem has been addressed by Broglia and Moos (this volume), who have corrected the neutron porosity logs for clay content and other factors. Their corrected values were used in the following analysis.

3. Not surprisingly, the sonic, density, and porosity tools do not respond in the same way to sharp changes in the properties of the formation (i.e., across contacts), and cross-plotting these data can lead to spurious trends and/or a misleadingly high degree of scatter in the crossplots. This problem is significant in the case of Hole 418A because the formation consists of pillow basalts, and pillow margins (contacts) occur at intervals on the order of $1 \mathrm{~m}$. To overcome the problem it is necessary to average the logged values over some reasonable interval. The data were logged at intervals of about $0.15 \mathrm{~m}$. After some experimentation we determined that averaging over about $7.6 \mathrm{~m}$ (51 data points) yields reasonable results (i.e., the intervals are large enough to yield useful average values but not so large that the number of intervals is too small to yield useful crossplots).

Average densities and sonic-wave traveltimes are summarized in Table 2. Neutron "densities" were estimated by first converting corrected neutron porosity to density (assuming a grain density of $2.93 \mathrm{Mg} / \mathrm{m}^{3}$ ) and averaging over the appropriate intervals. Mean traveltimes were calculated from the long-spacing (10-12 ft) sonic (DTL) data, which is less sensitive to disturbance near the borehole than the sonic (DT) log.

Velocity-density relations can be tested using either the gamma density or the density calculated from the neutron porosity log; the latter has the advantages of providing an independent estimate and of covering the interval between 525 and 600 mbsf in which gamma density data are not reliable. First, however, one would like to determine whether the gamma density and neutron porosity data are mutually consistent. For this purpose, the average $\log$ density and porosity data are plotted with laboratory data from Hole 418A (Donnelly, Francheteau, et al., 1980) in Figure 3.

The correlation between the averaged gamma densities, neutron porosities, and laboratory data appears to be poor because of variable grain densities, errors in density, errors in porosity, or a combination of these effects. But several observations suggest that these results are better than they might appear to be. The five data points having the lowest average porosities (less than $12 \%$ ) lie within the envelope of the laboratory data. Because each of the intervals represented by these data includes massive basalts, these are average values that should correspond most closely with the laboratory data. The intervals showing the lowest densities (less than $2.4 \mathrm{Mg} / \mathrm{m}^{3}$ ) span the breccia (Subunit $6 \mathrm{~A})$ at about $500 \mathrm{mbsf}$. Here the average log values correspond reasonably well with laboratory measurements $\left(\rho=2.36 \mathrm{Mg} / \mathrm{m}^{3}\right.$, porosity $=22.4 \%$ ). Finally, the averaged log data, taken at face value, span the same range of grain densities as the laboratory data. The scatter may reflect, at least in part, differences in large-scale porosity, which will displace the log values down the lines of constant grain density and toward lower bulk densities and porosities relative to the laboratory data.

Crossplots of sonic-wave slowness with the averaged gamma densities and densities calculated from the corrected neutron porosities are illustrated in Figures 4 and 5, respectively. The density data (Fig. 4) clearly follow the trend of the laboratory data. The two data points representing the breccia (Subunit 6A) 


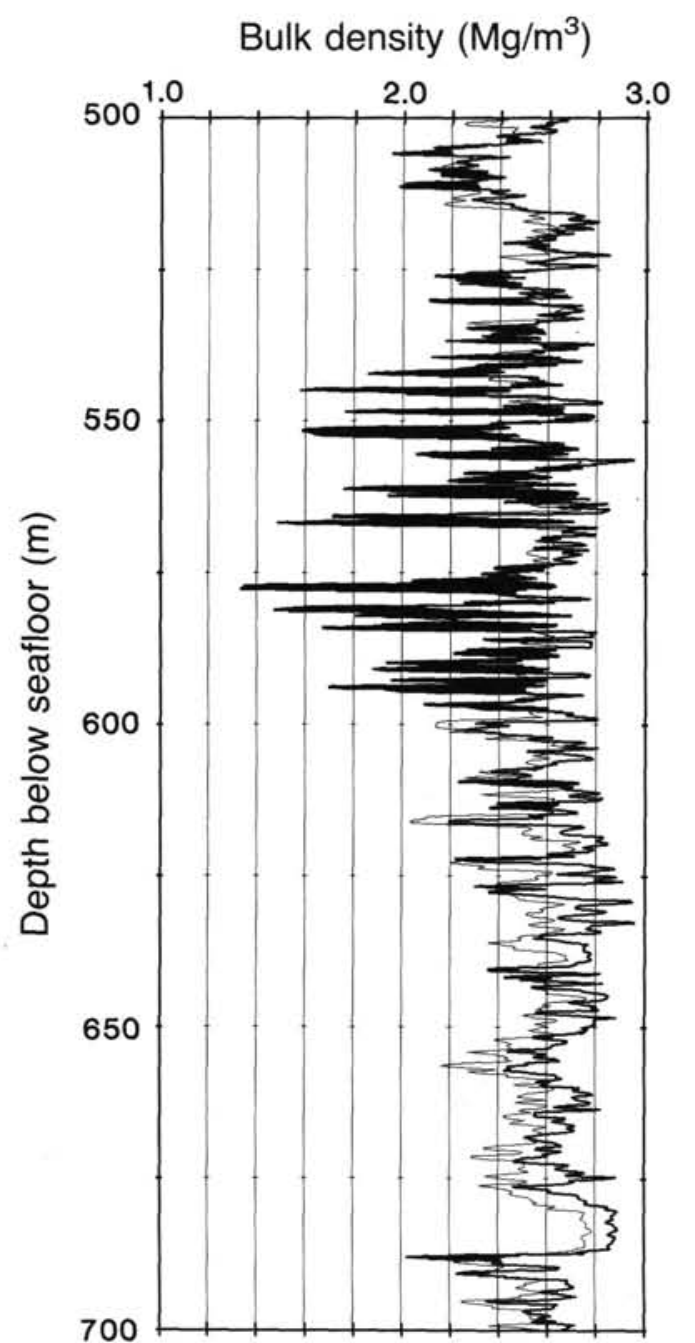

Figure 2. Site 418A density logs. Heavy line = gamma density. Light line $=$ minimum density calculated from uncorrected neutron porosity. Heavy shading indicates gamma density lower than minimum density.

fall below this line, but three quarters of the remaining data points lie within the standard error $\left(0.07 \mathrm{Mg} / \mathrm{m}^{3}\right)$ defined by the fit to the laboratory data, equation (1) (Carlson and Raskin, 1984). The neutron porosity data (Fig. 5) show a very similar pattern; only 8 of the 39 data points lie outside the error of the laboratory curve. In this case the data corresponding to the breccia of Subunit $6 \mathrm{~A}$ lie close to the laboratory curve because neither the porosity nor the velocity in the breccia is unusual, and the calculated density is too high. The low bulk density of the breccia (Table 2) reflects low grain densities, as opposed to high porosity.

This observation offers an explanation for the four data points that lie above the laboratory data curve in Figure 5. These data represent the interval between 470 and 500 mbsf, the lower part of Unit 5. The pillow basalts of Unit 5 differ from those deeper in the section in several respects. The natural gamma-ray (GR) log shows relatively high levels (20-25 GAPI units) extending to the base of the breccia, whereas gamma radiation below the breccia is lower, at 5-10 GAPI units (plate 1 of Shipboard Scientific Party, 1986). Furthermore, the DSDP Legs 51-53 scientific parties found significantly more alteration (smectites) in Unit 5 (Donnelly, Francheteau, et al., 1980), and the mean grain density of laboratory samples from Unit 5 is $2.86 \pm 0.01 \mathrm{Mg} / \mathrm{m}^{3}$,
Table 2. Summary of average log values.

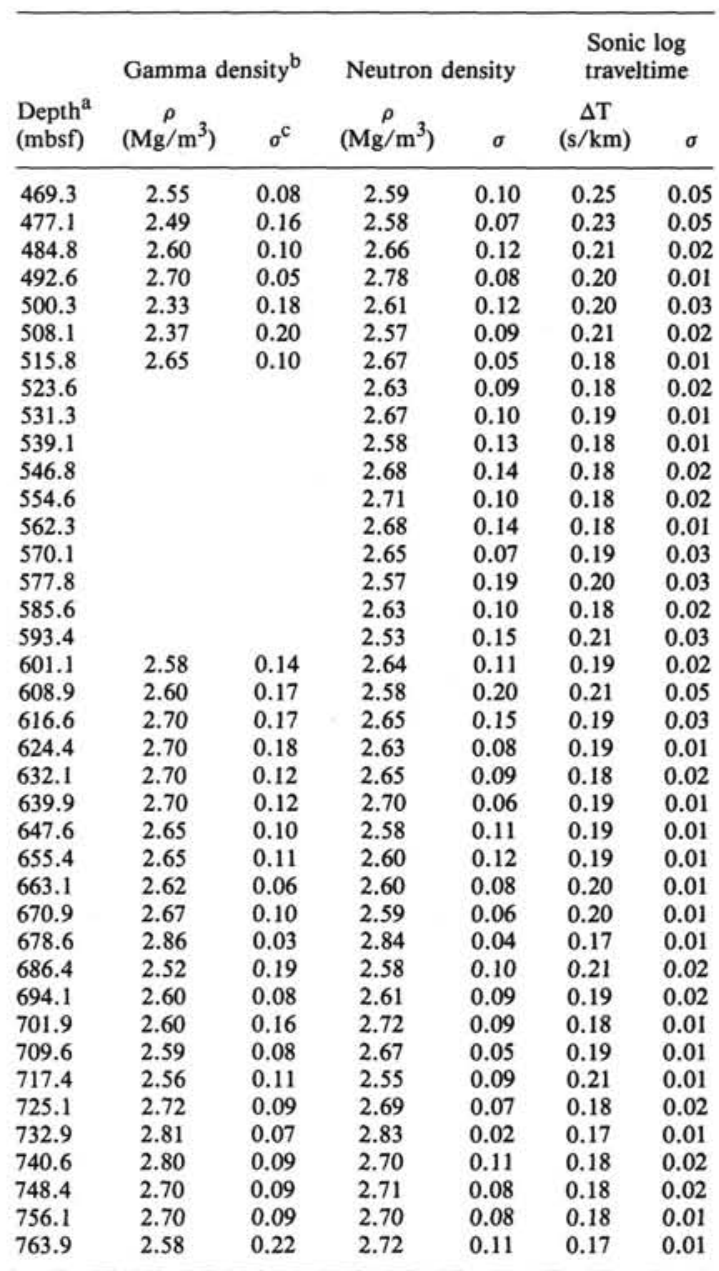

a Depth to top of interval.

b Calculated from corrected neutron porosity; grain density = $2.93 \mathrm{Mg} / \mathrm{m}^{3}$.

c Error in mean.

as opposed to $2.96 \pm 0.005 \mathrm{Mg} / \mathrm{m}^{3}$ for basalt samples recovered below Subunit $6 \mathrm{~A}$. These considerations suggest that Unit 5 is more altered than basalts lower in the section. If so, the densities for this interval shown in Figure 5 are erroneously high. The remaining 34 points correlate very well with the velocity-density relation for laboratory samples.

\section{CONCLUSION}

In a previous analysis, Carlson and Raskin (1984) concluded that the relationship between in-situ densities and seismic velocities of oceanic Layer 2, the extrusive pile, is quite different from the relationship between bulk densities and compressional-wave velocities in laboratory samples of seafloor basalts. This conclusion was, however, based largely on analyses of downhole logs from DSDP holes drilled in young oceanic crust. There is strong evidence that the velocity structure and, by implication, the physical state of Layer 2 change markedly with age (Houtz and Ewing, 1976). Thus, one might expect a difference in the relationship between density and velocity as well.

Logging results from ODP Leg 102 (Hole 418A) in 110-Maold crust provide important baseline data for old oceanic crust. Here we have used gamma density, neutron porosity, and sonic logging data to evaluate the relationship between density and velocity in situ. We must emphasize that our conclusions rest upon 


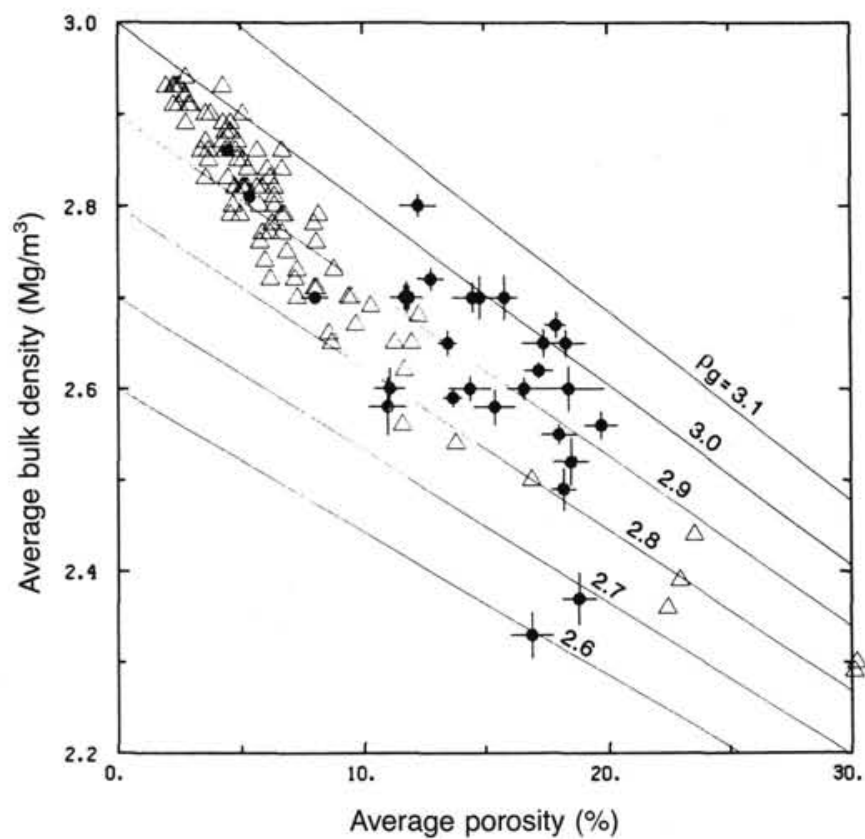

Figure 3. Hole 418A bulk density vs. porosity. Triangles = shipboard laboratory data (Donnelly, Francheteau, et al., 1980). Solid circles = average values from gamma density and corrected neutron porosity logs (see Table 2). Light lines are lines of constant grain density, $\rho \mathrm{g}$.

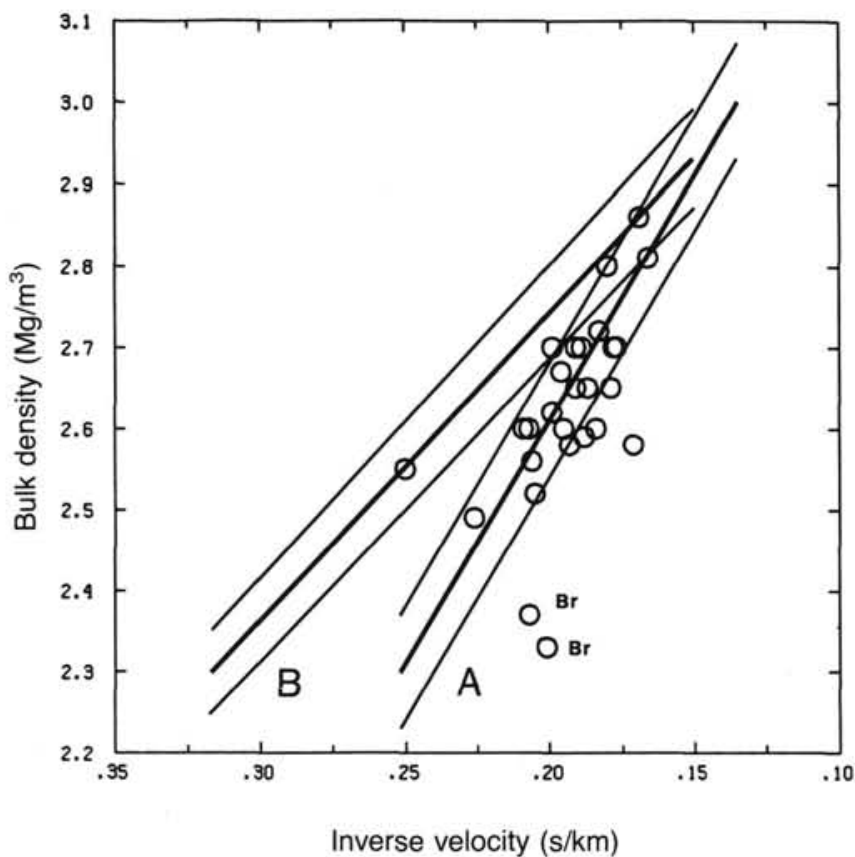

Figure 4. Averaged gamma density and sonic log data from Hole 418A (see Table 2) compared with time-average equation (line B) and best-fit laboratory relation (line $\mathrm{A}$ ). $\mathrm{Br}$ indicates data from breccia (Subunit 6A).

the following assumptions: (1) that the long-spaced sonic (DTL) $\log$ is accurate; (2) that aside from the poor data between 525 and $600 \mathrm{mbsf}$, the gamma density data are accurate; (3) that the neutron porosity data were adequately corrected for bound water and other effects; and (4) that a grain density of $2.93 \mathrm{Mg} / \mathrm{m}^{3}$ is sufficiently representative to estimate bulk densities from the porosity log.

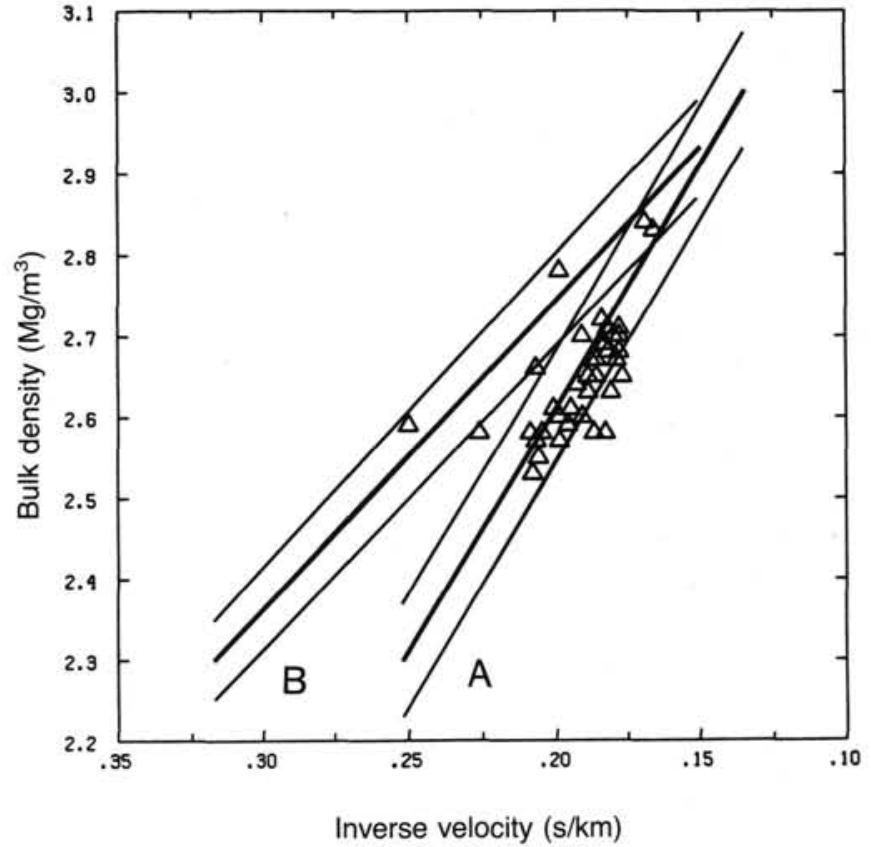

Figure 5. Densities estimated from corrected neutron porosity log and sonic log data from Hole 418A (see Table 2) compared with time-average equation (line B) and best-fit laboratory relation (line A).

We find that crossplots of both gamma density and density calculated from the porosity log with sonic log data are consistent with the previously established velocity-density relation for laboratory samples and are quite different from the trend based on logging in young oceanic crust (Figs. 4 and 5). Thus, we conclude that there is a significant change with age, not only in the seismic structure of Layer 2 but in the relationship between physical properties as well. For most of the oceanic crust, the best velocity-density relation is given by equation (1); equation (2) applies only to Layer 2 and only where the crust is less than about $20 \mathrm{Ma}$ in age. Referring to Table 1 , we find that the density of Layer 2 is 2.63 to $2.68 \mathrm{Mg} / \mathrm{m}^{3}, 0.1$ to $0.2 \mathrm{Mg} / \mathrm{m}^{3}$ lower than the preferred estimate of Carlson and Raskin (1984). Consequently, the mean density of oceanic crust more than $20 \mathrm{Ma}$ old is also lower-2.85 $\pm 0.05 \mathrm{Mg} / \mathrm{m}^{3}$, as opposed to about $2.9 \mathrm{Mg} / \mathrm{m}^{3}$.

Finally, it is interesting to compare these values with the estimated density of continental crust. It is commonly assumed that the continental crust has a density near $2.7 \mathrm{Mg} / \mathrm{m}^{3}$. However, based on gravity anomalies over granitic intrusives, Bott (1982) noted that the density of the upper crust is probably in the neighborhood of $2.75 \mathrm{Mg} / \mathrm{m}^{3}$. Woollard (1962) found that the average density of 1158 samples of basement rock from North America is $2.74 \mathrm{Mg} / \mathrm{m}^{3}$. Woollard (1966) also noted that in isostatically compensated regions the depth of the crust increases about $7.5 \mathrm{~km}$ per $1 \mathrm{~km}$ increase in elevation, suggesting a density contrast between the crust and mantle of about $0.39 \mathrm{Mg} / \mathrm{m}^{3}$ and a mean crustal density in the range 2.87 to $3.0 \mathrm{Mg} / \mathrm{m}^{3}$. Although more data and further analyses are needed to confirm either estimate, our results suggest that the estimated densities of continental and oceanic crust are comparable.

\section{ACKNOWLEDGMENTS}

We wish to thank Captain Oonk and the crew of the JOIDES Resolution and the ODP shipboard and shorebased staff for the success of logging operations on ODP Leg 102. We also wish to thank C. Broglia and D. Moos for providing the corrected logs for our analysis. This research was supported by Joint Oceanographic Institutions, Inc., and 
U.S. Scientific Advisory Committee. Texas A\&M Geodynamics Research Institute contribution no. 64 .

\section{REFERENCES}

Becker, K., Von Herzen, R. P., Francis, T.J.G., Anderson, R. N., Honnerez, J., Adamson, A. C., Alt, J. C., Emmerman, R., Kempton, P. D., Kinoshita, H., Laverne, C., Mottl, M. J., and Newmark, R. L., 1982. In situ electrical resistivity and bulk porosity of the oceanic crust Costa Rica Rift. Nature, 300:594-598.

Bott, M.H.P., 1982. The Interior of the Earth: Its Structures, Constitution and Evolution (2nd ed.): New York (Elsevier).

Cann, J. R., and Von Herzen, R. P., 1983. Downhole logging at Deep Sea Drilling Project Sites 501, 504 and 505, near the Costa Rica Rift. In Cann, J. R., Langseth, M. G., Honnorez, J., Von Herzen, R. P., White, S. M., et al., Init. Repts. DSDP, 69: Washington (U.S. Govt. Printing Office), 281-299.

Carlson, R. L., and Raskin, G. S., 1984. Density of the ocean crust. Nature, 311:555-558.

Carlson, R. L., and Wilkens, R. H., 1983. Seismic crustal structure and the elastic properties of rocks recovered by drilling in the Philippine Sea. In Hilde, T.W.C., and Uyeda, S. (Eds.), Geodynamics of the Western Pacific-Indonesian Region: Am. Geophys. Union Geodynamics Series, 11:127-136.

Christensen, N. J., Blair, S. C., Wilkens, R. H., and Salisbury, M. H., 1980. Compressional wave velocities, densities, and porosities of basalts from Holes 417A, 417D, and 418A, Deep Sea Drilling Projects Legs 51-53. In Donnelly, T., Francheteau, J., Bryan, W., Robinson, P., Flower, M., Salisbury, M., et al., Init. Repts. DSDP, 51, 52, 53, Pt. 2: Washington (U.S. Govt. Printing Office), 1467-1371.

Christensen, N. I., and Salisbury, M. H., 1975. Structure and constitution of the lower oceanic crust. Rev. Geophys., 13:57-86.

1982. Lateral heterogeneity in the seismic structure of the ocean crust inferred from velocity studies in the Bay of Islands ophiolite, Newfoundland. Geophys. J. R. Astron. Soc., 68:675-688.

Christensen, N. I., and Smewing, J. D., 1981. Geology and seismic structure of the northern section of the Oman ophiolite. J. Geophys. Res., 86:2545-2556.

Donnelly, T., Francheteau, J., Bryan, W., Robinson, P., Flower, M., Salisbury, M., et al., 1980. Init. Repts. DSDP, 51, 52, 53: Washington (U.S. Govt. Printing Office).

Fountain, D. M., Carlson, R. L., Salisbury, M. H., and Christensen, N. I., 1975. Possible lower crustal rocks recovered on Leg 31 by deep sea drilling in the Philippine Sea. Mar. Geol., 19:M75-M80.
Hamano, Y., 1980. Physical properties of basalts from Holes 417D and 418A. In Donnelly, T., Francheteau, J., Bryan, W., Robinson, P., Flower, M., Salisbury, M., et al., Init. Repts. DSDP, 51, 52, 53, Pt. 2: Washington (U.S. Govt. Printing Office), 1457-1466.

Houtz, R., and Ewing, J., 1976. Upper crustal structure as a function of plate age. J. Geophys. Res., 81:2490-2498.

Kirkpatrick, R. J., 1979. The physical state of the oceanic crust: results of downhole geophysical logging in the Mid-Atlantic Ridge at $23^{\circ} \mathrm{N}$. J. Geophys. Res., 84:178-188.

Purdy, G. M., 1983. The seismic structure of 140 myr old crust in the western central Atlantic Ocean. Geophys. J. R. Astron. Soc., 72: 115-137.

Raitt, R. W., 1963. The crustal rocks. In Hill, M. N. (Ed.), The Sea (Vol. 3): New York (Wiley), 84-102.

Salisbury, M. H., and Christensen, N. I., 1978. The seismic velocity structure of a traverse through the Bay of Islands ophiolite complex, Newfoundland, an exposure of oceanic crust and upper mantle. $J$. Geophys. Res., 83:805-817.

Salisbury, M. H., Scott, J. H., et al., 1986. Proc. ODP, Init. Repts., 102: College Station, TX (Ocean Drilling Program).

Salisbury, M. H., Stephen, R., Christensen, N. I., Francheteau, J., Hamano, Y., Hobart, M., and Johnson, D., 1980. The physical state of the upper levels of Cretaceous oceanic crust from the results of logging, laboratory studies and the oblique seismic experiment at DSDP Sites 417 and 418. In Donnelly, T., Francheteau, J., Bryan, W., Robinson, P., Flower, M., Salisbury, M., et al., Init. Repts. DSDP, 51 , 52, 53, Pt. 2: Washington (U.S. Govt. Printing Office), 113-134.

Shipboard Scientific Party, 1986. Site 418: Bermuda Rise. In Salisbury, M. H., Scott, J. H., et al., Proc. ODP, Init. Repts., 102: College Station, TX (Ocean Drilling Program), 95-149.

Shor, G. G., 1971. Structure of the Pacific Basin. In Maxwell, A. (Ed.), The Sea (Vol. 4): New York (Wiley), 3-27.

Stephen, R. A., 1985. Seismic anisotropy in the upper oceanic crust. $J$. Geophys. Res., 90:11383-11396.

Woollard, G. P., 1962. The relation of gravity anomalies to surface elevation, crustal structure, and geology. Geophys. Rept. Polar Res. Cent., Univ. Wisconsin, 62-9.

1966. Regional isostatic relations in the United States. In Strenhard, J. S., and Smith, T. J. (Eds.), The Earth Beneath the Continents: Washington (Am. Geophys. Union), 557-594.

Date of initial receipt: 25 May 1987

Date of acceptance: 5 August 1987

Ms 102B-124 